\title{
Endoscopic vs. microscopic transsphenoidal surgery for Cushing's disease: a systematic review and meta-analysis
}

\author{
Leonie H. A. Broersen ${ }^{1,2} \cdot$ Nienke R. Biermasz ${ }^{1,2} \cdot$ Wouter R. van Furth $^{2,3} \cdot$ Friso de Vries $^{1,2} \cdot$ Marco J. T. Verstegen $^{2,3}$. \\ Olaf M. Dekkers ${ }^{1,4} \cdot$ Alberto M. Pereira $^{1,2}$
}

Published online: 16 May 2018

(c) The Author(s) 2018

\begin{abstract}
Purpose Systematic review and meta-analysis comparing endoscopic and microscopic transsphenoidal surgery for Cushing's disease regarding surgical outcomes (remission, recurrence, and mortality) and complication rates. To stratify the results by tumor size.

Methods Nine electronic databases were searched in February 2017 to identify potentially relevant articles. Cohort studies assessing surgical outcomes or complication rates after endoscopic or microscopic transsphenoidal surgery for Cushing's disease were eligible. Pooled proportions were reported including $95 \%$ confidence intervals.

Results We included 97 articles with 6695 patients in total (5711 microscopically and 984 endoscopically operated). Overall, remission was achieved in 5177 patients $(80 \%)$, with no clear difference between both techniques. Recurrence was around $10 \%$ and short term mortality $<0.5 \%$ for both techniques. Cerebrospinal fluid leak occurred more often in endoscopic surgery (12.9 vs. $4.0 \%$ ), whereas transient diabetes insipidus occurred less often (11.3 vs. 21.7\%). For microadenomas, results were comparable between both techniques. For macroadenomas, the percentage of patients in remission was higher after endoscopic surgery (76.3 vs. 59.9\%), and the percentage recurrence lower after endoscopic surgery (1.5 vs. 17.0\%).

Conclusions Endoscopic surgery for patients with Cushing's disease reaches comparable results for microadenomas, and probably better results for macroadenomas than microscopic surgery. This is present despite the presumed learning curve of the newer endoscopic technique, although confounding cannot be excluded. Based on this study, endoscopic surgery may thus be considered the current standard of care. Microscopic surgery can be used based on neurosurgeon's preference. Endocrinologists and neurosurgeons in pituitary centers performing the microscopic technique should at least consider referring Cushing's disease patients with a macroadenoma.
\end{abstract}

Keywords Cushing's disease $\cdot$ Transsphenoidal surgery $\cdot$ Endoscopic surgery $\cdot$ Microscopic surgery

Electronic supplementary material The online version of this article (https://doi.org/10.1007/s11102-018-0893-3) contains supplementary material, which is available to authorized users.

Leonie H. A. Broersen

L.H.A.Broersen@lumc.nl

1 Department of Medicine, Division of Endocrinology, Leiden University Medical Centre, Albinusdreef 2, 2333 ZA Leiden, The Netherlands

2 Center for Endocrine Tumors Leiden (CETL), Leiden University Medical Center, Albinusdreef 2, 2333 ZA Leiden, The Netherlands

3 Department of Neurosurgery, Leiden University Medical Centre, Albinusdreef 2, 2333 ZA Leiden, The Netherlands

4 Department of Clinical Epidemiology, Leiden University Medical Center, Albinusdreef 2, 2333 ZA Leiden, The Netherlands

\section{Introduction}

Cushing's disease is caused by an adrenocorticotropic hormone (ACTH)-secreting pituitary adenoma, with an estimated incidence of 1.2-2.4 per million each year [1]. The resulting excess of glucocorticoids induces insulin resistance, dyslipidemia, central obesity, hypercoagulability, and increases the risk of osteoporosis, hypertension, and neuropsychiatric disorders [2, 3]. First-choice treatment for Cushing's disease is transsphenoidal pituitary surgery, with selective adenoma removal [4]. Despite biochemical cure, mortality risk in Cushing's disease patients remains increased [5].

Two main techniques have been used for transsphenoidal pituitary surgery: microscopic and endoscopic surgery. 
Furthermore, the microscopic and endoscopic techniques have been used in combination, in which the endoscope was used to visually confirm findings of the microscope. The microscopic technique was the established method to perform transsphenoidal surgery, until the first reports on endoscopic pituitary surgery were published, starting in 1992 [6]. With the operating microscope, intraoperative differentiation of pathologic tissue from normal tissue is achieved by providing three-dimensional vision in a direct line to the pituitary [7, 8]. Endoscopic pituitary surgery provides a broader field of vision using endoscopes with various angles in close proximity to the pituitary, however losing the three-dimensional vision and thus depth perception [6, 8]. From the introduction of the endoscope in transsphenoidal surgery, most surgical centers have chosen for microscopy or endoscopy. Only few small cohort studies have compared the microscopic and endoscopic surgical techniques in Cushing's disease performed in the same center [9-12]. No clear differences in remission rate or surgical morbidity between microscopic and endoscopic surgery could be shown. However, the studies had only limited statistical power [9].

Several systematic reviews have compared endoscopic and microscopic surgical techniques in a heterogeneous population of patients with various pituitary adenomas. These studies have found a reduced rate of some complications (postoperative diabetes insipidus, rhinological complications), but an increased rate of other complications (vascular complications, cerebrospinal fluid leak, anterior pituitary hormone deficiency) for the endoscopic technique $[8,13,14]$. These differences in outcomes may partially be explained by the surgeon's attempt for a more radical tumor excision with the newer endoscopic technique with better vision, by the larger proportion of more challenging macroadenomas and re-operations reported in literature, and by improved rhinological care by an otolaryngologist after endoscopic surgery $[8,13,14]$. Until now, no systematic review has been published comparing the microscopic to the endoscopic surgical technique in Cushing's disease. Convincing evidence supporting the choice for one of both techniques in the treatment of Cushing's disease, either based on treatment results or complication rate, is thus lacking.

\section{Study aims}

The primary aims of this systematic review were to compare remission and recurrence rate, and mortality, after microscopic vs. endoscopic transsphenoidal pituitary surgery for Cushing's disease. Secondary study aims were to compare complication rates, remission and recurrence rates stratified by tumor size, and percentage remission after a repeat transsphenoidal surgical procedure.

\section{Methods}

\section{Eligibility criteria}

Randomized controlled trials and cohort studies in Cushing's disease assessing outcomes after endoscopic or microscopic transsphenoidal surgery were eligible. Studies describing endoscope-assisted microscopic surgery were considered microscopic surgery. Single-arm studies as well as direct comparisons were considered, mainly because we did not expect many direct comparisons in a single cohort. Study outcomes of interest were remission rate, recurrence rate, short and long term mortality risk, and complications of surgery. Studies reporting outcomes after primary as well as after repeat transsphenoidal surgery were eligible. Studies reporting $<10$ patients with Cushing's disease per treatment group were excluded to minimize the risk of selection bias. Articles were also excluded if the study included children only, if the study did not clearly report which surgery type was performed, or if no distinction between surgery types was made in the analysis. Articles including patients with selective adenomectomy as well as partial or total hypophysectomy were included as long as total hypophysectomy did not exceed 5\%. If described separately, patients with total hypophysectomy were excluded from analyses. If multiple articles described (partially) the same population, the article with the largest cohort was included per analysis. Articles irretrievable online were requested by contacting the authors. Articles still irretrievable, but with sufficient data mentioned in the abstract for reliable eligibility assessment and data extraction, were included. Only articles in English were considered.

\section{Search strategy}

To identify potentially relevant articles, PubMed, Embase, Web of Science, COCHRANE Library, CENTRAL, Emcare, LWW, ScienceDirect and Wiley were systematically searched in February 2017 in cooperation with a specialized librarian (see Online Resource 1 for the complete search strategy). References of included articles were searched and the search strategy was manually extended in PubMed with the search term 'pituitary adenoma' to find more potentially eligible studies.

\section{Data extraction}

All identified articles were imported in endnote 8 (Thomson Reuters, Philadelphia, PA, USA). Studies were screened by title and abstract and potentially relevant articles were reviewed in detail to assess eligibility. Potentially relevant 
articles were screened and reviewed by two reviewers independently and disagreement was solved by consensus. The meta-analysis of observational studies in epidemiology (MOOSE) guidelines were used for reporting [15].

\section{Risk of bias assessment}

For risk of bias analysis we used a component approach. Risk of bias was assessed by two independent reviewers for all included studies using the following components, which could potentially bias a reported association between surgical technique and outcome:

1. Inclusion of patients (consecutive inclusion or a random sample is considered low risk of bias)

2. Loss to follow-up ( $<5 \%$ is considered low risk of bias)

3. Criteria for diagnosis of Cushing's disease (see below)

4. Clear reporting of criteria for main study outcome. For most studies the main outcome is remission of Cushing's disease. If remission is not a study outcome, studies will be checked for reporting criteria for their primary study outcome, most often one or more complications of treatment.

As criteria for diagnosis of Cushing's disease vary widely over time and per study center, and study outcomes also vary per included article, mentioning the criteria for diagnosis and study outcome is considered a low risk of bias. Classification of interventions is not considered in this risk of bias analysis, because the interventions of interest are one-time procedures and therefore unlikely to be misclassified.

Risk of bias analysis was used to explore potential heterogeneity. As most studies did not compare the two surgical techniques directly, confounding was not judged at the study level, but was assessed by comparing baseline characteristics between microscopically and endoscopically treated patients. Variables influencing the choice of treatment as well as co-interventions that could affect treatment outcome are reported.

\section{Study endpoints}

The main outcomes of this study were the percentage of patients reaching remission, the recurrence rate, and the short term mortality risk after microscopic and endoscopic transsphenoidal pituitary surgery for Cushing's disease. Secondary outcomes were complication rates, rates of remission and recurrence stratified by tumor size, and the percentage of patients to reach remission after a repeat transsphenoidal surgical procedure. Because of the low number of studies with direct comparisons, percentages were reported per surgical technique.
Remission was considered direct postoperatively (until 6 months post-surgery). Hydrocortisone dependency was calculated as a percentage of the total patient population to maintain comparability with remission rate. Disease recurrence was estimated as percentage of the patients with initial remission. Mortality risk was analysed for short-term mortality ( $<3$ months after surgery). Long-term mortality risk ( $\geq 3$ months after surgery) was not analysed, as time since surgery was often unclear. Articles reporting mortality without mentioning time since surgery were excluded from mortality analyses.

The following complications were assessed: cerebrospinal fluid leak (CSF leak), meningitis, syndrome of inappropriate antidiuretic hormone secretion (SIADH), anterior pituitary hormone deficiency, thromboembolism, bleeding, transient diabetes insipidus, permanent diabetes insipidus, and psychopathology. If an article described diabetes insipidus without specifying the duration, it was excluded from diabetes insipidus analyses.

\section{Statistical analysis}

Percentages were pooled in a random-effects logistic regression model if there were $\geq 5$ articles per analysis. A fixedeffects model was used for analyses with $<5$ studies. The Freeman-Tukey arcsine transformation was used to stabilize variances, in order to prevent exclusion of studies with 0 or $100 \%$ as outcome. All analyses were performed using Stata 11.2 (Stata Corp., College Station, TX, USA).

Sensitivity analyses were performed to assess the potential effect of high risk of selection bias studies by excluding articles in which inclusion of patients was not consecutive or a random sample and/or loss to follow-up was $\geq 5 \%$. Of note, articles not mentioning method of inclusion or loss to follow-up were not excluded in these sensitivity analyses, as this would not leave sufficient articles for analysis (13 for microscopic surgery and one for endoscopic surgery only). Sensitivity analyses were also performed for studies with a study period starting from the year 2000 or later, to assess the potential cohort effect of calendar year of surgery. Finally, sensitivity analyses were performed for studies reporting specific criteria for diagnosis of Cushing's disease (pituitary imaging or petrosal sinus sampling, and at least one of the following laboratory measurements or tests: increased morning serum cortisol, increased 24-h urinary free cortisol, increased midnight salivary cortisol, no suppression of cortisol after a low dose dexamethasone test combined with a non-suppressed ACTH) to increase reliability of including only Cushing's disease patients, as well as for studies using at least a low dose dexamethasone test in the determination of remission status to increase test homogeneity, and for studies assessing remission status 3-6 months postoperatively, as this is a more reliable timeframe 
to correctly assess remission status than direct postoperatively [16].

\section{Results}

\section{Study selection}

The initial search identified 932 articles. Searching through references of included articles and manually extending the search in PubMed with the search term 'pituitary adenoma' identified another 16 articles, thereby yielding a total of 948 articles. After screening the articles by title and abstract, 685 articles were excluded, leaving 263 articles for detailed review. Reasons for exclusion are summarized in Fig. 1. There were 97 articles included in this review, two of which based on abstract only $[17,18]$.

\section{Study characteristics (online resource 2)}

No RCTs were performed comparing microscopic to endoscopic surgery. There were 71 studies reporting on microscopic surgery only [4, 7, 17, 19-86], 22 studies reporting on endoscopic surgery only [18, 87-107], and four studies from four different centers reporting on both microscopic and endoscopic surgery in the same center [9-12]. Studies reporting on both techniques were entered twice in the tables and analyses, separately for each of the techniques. Articles were published between 1978 and 2017 for microscopic surgery and from 2001 to 2017 for endoscopic surgery. Two included articles reported only results for patients after repeat transsphenoidal surgery $[65,82]$. A total of 5711 patients were included for the microscopic technique, and 984 patients for the endoscopic technique.

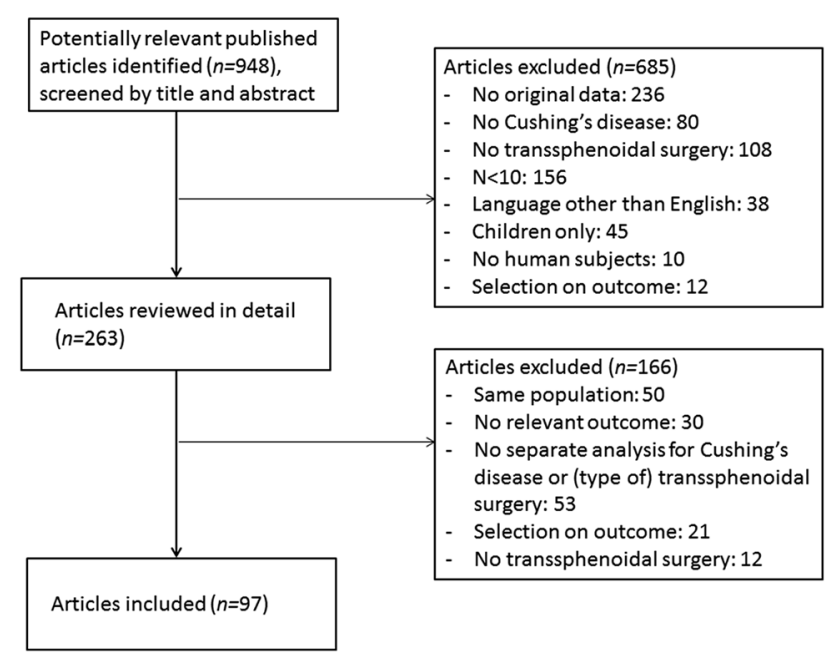

Fig. 1 Flow-chart of inclusion of articles in this systematic review

\section{Risk of bias assessment}

Detailed risk of bias assessment per included article is shown in Online Resource 3. Reported loss to follow-up [reported in 35 studies (36\%)] ranged from 0 to $26.9 \%$. Inclusion of consecutive patients or a random sample of patients was explicitly stated in 73 articles $(75 \%)$. There were 80 articles $(82 \%)$ that reported the criteria for Cushing's disease diagnosis, or that referred to the article in which the exact criteria were published. Criteria for main study outcome were reported in 88 articles (91\%). Remission of Cushing's disease was the main study outcome in 83 of these 88 articles $(94 \%)$.

Differences in baseline characteristics (confounding) are likely as treatment assignment was dependent on calendar year of surgery and center. There were only three articles describing both techniques in the same center and in the same calendar period (see Online Resource 2). Furthermore, there was a slight difference in average age at treatment (microscopy 21.5-50 years; endoscopy 31.9-55.7 years) and in percentage female (microscopy 67-93\%; endoscopy 57-95\%). Co-interventions that could influence treatment outcome are reported per article in Online Resource 3. Nine included articles (9\%) explicitly reported that no cointerventions were used, 20 articles (21\%) reported use of co-interventions before or shortly after treatment in part of their included patients. The remaining 68 articles (70\%) did not report on co-interventions.

\section{Study outcomes}

For a total of 91 study groups (87 articles), remission was the primary outcome of interest. Overall, remission was obtained in $80 \%(5177 / 6484)$ of patients. There were 48 articles reporting a (short and/or long term) mortality rate, and 60 articles reported the rate of, at least one, complication. For details of study outcomes at the individual study level, see Online Resource 4.

\section{Pooled proportions of surgical outcomes: remission, recurrence, mortality, and remission after repeat surgery (Fig. 2; Table 1)}

The percentage remission was similar for microscopically and endoscopically treated patients, both reaching around $80 \%$ remission. Hydrocortisone dependency was seen in $39.3 \%$ (95\% confidence interval [CI] 23.5-56.4\%) of patients after microscopic surgery and in $33.5 \%$ (95\% CI 13.3-57.3\%) after endoscopic surgery. Recurrence of disease occurred in around $10 \%$ of patients after both types of surgery. Average follow-up duration for studies reporting on disease recurrence was 1.0-15.4 years for microscopy and 1.4-5.9 years for endoscopy. Recurrence occurred after 


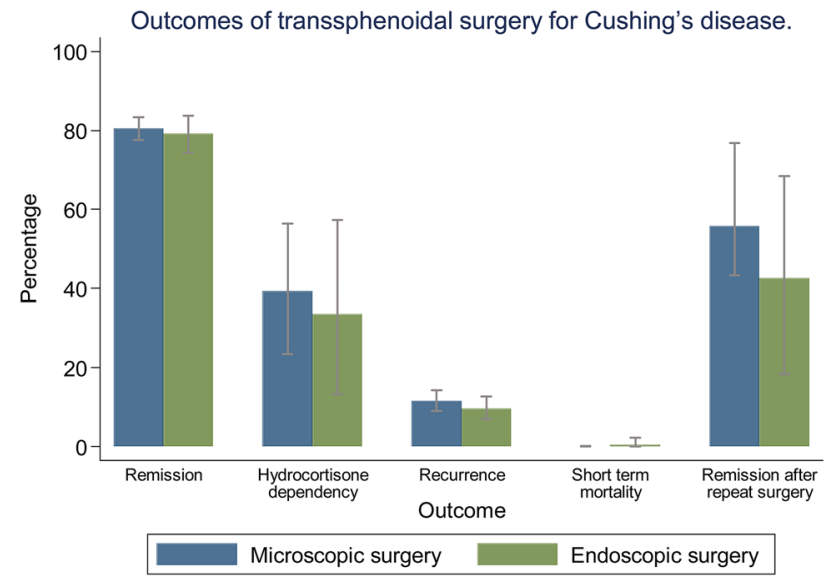

Fig. 2 Analysis of surgical outcomes of transsphenoidal surgery for Cushing's disease. Bars: 95\% confidence interval

an average of 6-76 months in studies using the microscopic technique, and after an average of 24-54 months in studies using the endoscopic technique. Short term mortality was $0.0 \%$ (95\% CI $0.0-0.2 \%$ ) for microscopic surgery and $0.4 \%$ (95\% CI 0.0-2.2\%) for endoscopic surgery. The percentage of patients that obtained remission after a repeated transsphenoidal surgical procedure was $55.7 \%(95 \%$ CI 43.3-67.8\%) for microscopic surgery, and $42.6 \%$ (95\% CI 18.4-68.4\%) for endoscopic surgery. Measurements of treatment effect were consistent across individual studies, and spread of measurements is reflected by the $95 \%$ confidence interval of the outcomes of the analyses.

\section{Pooled proportions of complications after transsphenoidal pituitary surgery for Cushing's disease (Fig. 3; Table 1)}

Cerebrospinal fluid leak was reported less often in patients after microscopic surgery [4.0\% (95\% CI 2.3-6.1\%)], than after endoscopic surgery [12.9\% (95\% CI 5.8-22.1\%)]. Furthermore, SIADH, bleeding and permanent diabetes insipidus were seen slightly less often in patients after microscopic surgery, than in patients after endoscopic surgery. Transient diabetes insipidus was reported more often in patients after microscopic surgery [21.7\% (95\% CI 15.0-29.3\%)], than in patients after endoscopic surgery $[11.3 \%(95 \% \mathrm{CI}$ 6.6-17.1\%)]. Meningitis (around 0.4\%), anterior pituitary deficiency (around 10.5\%), and thromboembolism (little over $1 \%$ ), were seen in about equal percentages of patients, regardless of surgical technique. Psychopathology was reported in $0.7 \%$ (95\% CI $0.0-3.1 \%)$ of patients after
Table 1 Results of metaanalyses comparing microscopic and endoscopic surgery for Cushing's disease

\begin{tabular}{|c|c|c|c|c|}
\hline & \multicolumn{2}{|c|}{ Microscopic surgery } & \multicolumn{2}{|c|}{ Endoscopic surgery } \\
\hline & $\begin{array}{l}\text { Estimated } \\
\text { percentage }\end{array}$ & $95 \% \mathrm{CI}$ & $\begin{array}{l}\text { Estimated } \\
\text { percentage }\end{array}$ & $95 \% \mathrm{CI}$ \\
\hline \multicolumn{5}{|l|}{ Meta-analysis of surgical outcomes } \\
\hline Remission & 80.5 & $77.6-83.3$ & 79.2 & $74.3-83.8$ \\
\hline Hydrocortisone dependency & 39.3 & $23.5-56.4$ & 33.5 & $13.3-57.3$ \\
\hline Recurrence & 11.5 & $9.0-14.3$ & 9.6 & $6.9-12.7$ \\
\hline Short term mortality & 0.0 & $0.0-0.2$ & 0.4 & $0.0-2.2$ \\
\hline Remission after repeat surgery & 55.7 & $43.3-67.8$ & 42.6 & $18.4-68.4$ \\
\hline \multicolumn{5}{|l|}{ Meta-analysis of complications } \\
\hline Cerebrospinal fluid leak & 4.0 & $2.3-6.1$ & 12.9 & $5.8-22.1$ \\
\hline Meningitis & 0.6 & $0.1-1.3$ & 0.1 & $0.0-1.0$ \\
\hline $\begin{array}{l}\text { Syndrome of inappropriate antidiuretic } \\
\text { hormone secretion }\end{array}$ & 3.5 & $1.3-6.6$ & 5.2 & $2.9-8.0$ \\
\hline Anterior pituitary hormone deficiency & 9.4 & $5.1-14.8$ & 11.5 & $5.7-18.8$ \\
\hline Thromboembolism & 1.2 & $0.4-2.3$ & 1.5 & $0.4-3.0$ \\
\hline Bleeding & 1.9 & $0.7-3.5$ & 3.7 & $0.8-8.3$ \\
\hline Transient diabetes insipidus & 21.7 & $15.0-29.3$ & 11.3 & $6.6-17.1$ \\
\hline Permanent diabetes insipidus & 2.4 & $1.1-4.1$ & 4.0 & $2.2-6.3$ \\
\hline Psychopathology & 0.7 & $0.0-3.1$ & - & - \\
\hline \multicolumn{5}{|c|}{ Meta-analysis of surgical outcomes according to tumor size } \\
\hline Remission for microadenoma & 85.5 & $81.2-89.3$ & 83.9 & $76.8-90.0$ \\
\hline Recurrence for microadenoma & 9.8 & $6.8-13.2$ & 8.1 & $4.3-12.8$ \\
\hline Remission for macroadenoma & 59.9 & $52.0-67.6$ & 76.3 & $64.3-86.7$ \\
\hline Recurrence for macroadenoma & 17.0 & $5.6-31.5$ & 1.5 & $0.0-6.4$ \\
\hline
\end{tabular}




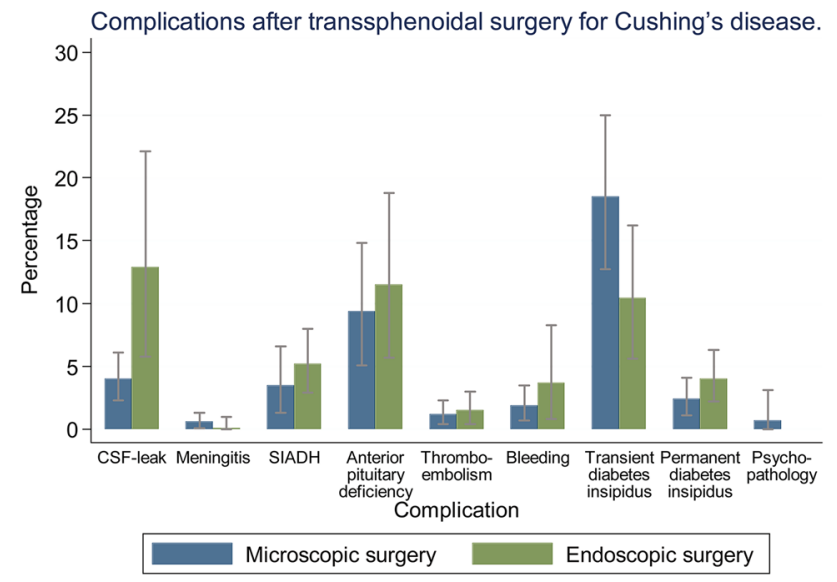

Fig. 3 Analysis of complication rates after transsphenoidal surgery for Cushing's disease. Bars: 95\% confidence interval

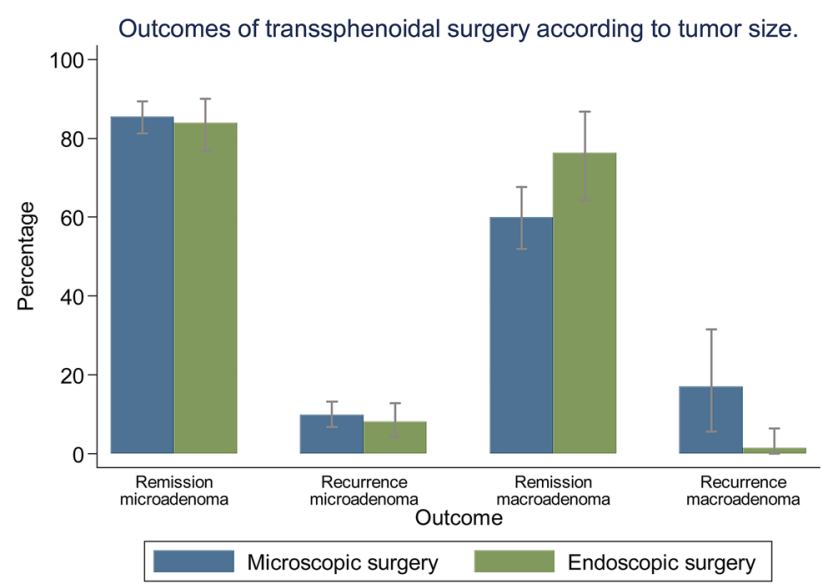

Fig. 4 Analysis of surgical outcomes of transsphenoidal surgery for Cushing's disease, stratified by tumor size. Bars: $95 \%$ confidence interval

microscopic surgery. There were no articles on endoscopic surgery reporting on psychopathology.

\section{Pooled proportions of remission and disease recurrence according to tumor size (Fig. 4; Table 1)}

For microadenomas, the percentage of patients that achieved remission was $85.5 \%$ (95\% CI 81.2-89.3\%) after microscopic surgery vs. $83.9 \%$ (95\% CI 76.8-90.0\%) after endoscopic surgery. Recurrence of disease occurred in $9.8 \%$ (95\% CI 6.8-13.2\%) of patients after microscopic surgery vs. $8.1 \%$ (95\% CI 4.3-12.8\%) after endoscopic surgery.

For macroadenomas, the percentage of patients that achieved remission was 59.9\% (95\% CI 52.0-67.6\%) after microscopic surgery vs. $76.3 \%$ (95\% CI 64.3-86.7\%) after endoscopic surgery. Disease recurrence occurred in $17.0 \%$ (95\% CI 5.6-31.5\%) after microscopic surgery vs. $1.5 \%$ (95\% CI 0.0-6.4\%) after endoscopic surgery.

\section{Sensitivity analysis}

Generally, results from sensitivity analyses were similar to those found in the main analyses. Detailed results for sensitivity analyses and the number of studies per analysis can be found in Online Resource 5.

\section{Discussion}

We performed a systematic review to compare surgical outcomes after microscopic vs. endoscopic transsphenoidal pituitary surgery for Cushing's disease. Regardless of surgical technique, remission rates were around $80 \%$ and recurrence rates around $10 \%$ after transsphenoidal surgery. There were no clear differences between surgical techniques regarding mortality, or remission rates after repeat transsphenoidal surgery. Complication rates ranged from $0.1 \%$ (for meningitis) to $21.7 \%$ (for transient diabetes insipidus), with minor differences between surgical techniques. Remission and recurrence rates for microadenomas were similar for both surgical techniques. However, remission rate was higher for macroadenomas ( 76.3 vs. $59.9 \%$ ), with a lower recurrence rate (1.5 vs. $17.0 \%)$ after endoscopic surgery than after microscopic surgery. Thus, for macroadenomas only there seems to be an advantage of the endoscopic over the microscopic surgical technique for transsphenoidal treatment of Cushing's disease.

This is the first systematic review comparing microscopic and endoscopic transsphenoidal pituitary surgery specifically for Cushing's disease. We found comparable remission and mortality rates for both surgical techniques, which is in line with results of meta-analyses of heterogeneous populations of various pituitary adenomas, and some small cohort studies comparing both techniques directly for Cushing's disease [8-14]. Differences in complications rates found in meta-analyses of heterogeneous populations of various pituitary adenomas can partially be confirmed by our analysis (reduced rate of transient diabetes insipidus, and increased rate of vascular complications and cerebrospinal fluid leak for the endoscopic technique) $[8,13,14]$. The increased rate of anterior pituitary hormone deficiency for endoscopic transsphenoidal surgery was not found in the present study [14]. The difference in remission rate between the surgical techniques for macroadenomas, but not microadenomas, is in line with the results from a cohort study on multiple pituitary adenomas described separately, that reported an advantage of the endoscopic technique for macroadenomas, but not for microadenomas. This difference was statistically 
significant for the population as a whole, but was supported by differences in the same direction for all included types of pituitary adenoma, including Cushing's disease [11].

In interpreting the results, the following study limitations need to be taken into account. Most included studies in this study were single-arm studies, limiting the possibilities of directly comparing microscopic to endoscopic transsphenoidal surgery. However, as treatment assignment in most studies was based on availability of a specific technique in the surgical center, for endoscopy often based on preference of the neurosurgeons after a test period, other baseline characteristics, such as age and gender distribution, are unlikely to have influenced treatment assignment largely. As microscopy was the established surgical technique until the introduction of the endoscope for transsphenoidal surgery for Cushing's disease, year of surgery varied widely for included studies [108]. For endoscopic surgery, a learning curve has been described [97, 98]. As most studies did not report patient level data, the effect of a potential learning curve per surgical center could not be analyzed in this study. However, to avoid measuring an effect of a collective learning curve, the earliest studies using endoscopic surgery, with study periods starting before the year 2000, were excluded in the previously mentioned sensitivity analysis.

Included studies showed heterogeneity in criteria used for diagnosing Cushing's disease, both in tests used to determine remission status, and in time period after surgery for assessment of remission status. Sensitivity analyses showed generally comparable results to the main analyses. Differences are likely to have occurred because of the small number of studies included in these sensitivity analyses compared to the number of studies in the corresponding main analyses. However, too many studies did not clearly report loss to follow-up, method of inclusion of patients, or both, preventing us from performing a sensitivity analysis excluding both articles with unclear risk of selection bias as well as high risk of bias, as this restriction would have resulted in one low bias risk article only in endoscopy. Follow-up duration differed between publications, which could potentially lead to a bias in the analysis of recurrences, as this is the only truly long-term outcome. However, given that most recurrences occur early after initial surgery (with only one microscopic study reporting average time to recurrence longer than any average follow-up duration of an endoscopic study), and given that the average follow-up duration for studies reporting on disease recurrence is $1.0-15.4$ years for microscopy and 1.4-5.9 years for endoscopy, the bias is probably not very large.

From a pathophysiological perspective, the similar results yielded for microscopic and endoscopic transsphenoidal surgery may be explained by the large percentage of microadenomas in the population of Cushing's disease patients [109]. For microadenomas, there may not be an advantage in increasing field of vision at the cost of losing three-dimensional vision and thereby depth perception $[6,8]$. Most likely, due to their small size, microadenomas are completely within the field of vision regardless of surgical technique. Our results concerning remission and recurrence for microadenomas indeed showed no clear advantage for either technique. For macroadenomas, we did show an advantage of the endoscopic surgical technique. As macroadenomas are larger and more often invasive, a broader field of vision in close proximity to the tumor may aid the neurosurgeon in achieving a complete tumor resection, causing higher remission and lower recurrence rates after endoscopic surgery. In microscopic surgery, these tumors are more often partially out of vision for the neurosurgeon. Unfortunately, due to lack of data, we were unable to perform separate analyses for invasive vs. non-invasive macroadenomas, as well as for small vs. larger microadenomas. The increased rate of cerebrospinal fluid leak after endoscopic transsphenoidal surgery may partially be explained by the neurosurgeon's attempt to achieve complete tumor resection also in more difficult cases with the newer endoscopic technique, whereas the reduced rate of transient diabetes insipidus may originate from the more precise tumor excision due to improved vision close to the tumor, causing less damage to the posterior lobe of the pituitary. Publication bias has been suggested as partial explanation for the increased rate of cerebrospinal fluid leak after endoscopic surgery, as more often challenging macroadenomas have been described [14].

For most Cushing's disease patients, this study shows no clear advantage of either microscopic or endoscopic transsphenoidal surgery regarding surgical outcomes and complication rates. For macroadenomas, the endoscopic technique yields better results regarding remission and recurrence rate. These results are present despite the presumed learning curve of the newer endoscopic technique within the study period, although confounding by indication and improved radiological investigations with time cannot be excluded. As most patients with Cushing's disease have microadenomas [109], there is no reason that all neurosurgical centers treating patients with Cushing's disease should change to the endoscopic technique. However, there is also no particular reason to keep using the microscopic technique for patients with Cushing's disease, other than neurosurgeon's preference. Based on this study, centers that choose to use the microscopic technique should consider referral of patients with Cushing's disease and a macroadenoma to another surgical center that performs endoscopic surgery.

Funding This research did not receive any specific grant from any funding agency in the public, commercial or not-for-profit sector. 


\section{Compliance with ethical standards}

Conflict of interest The authors declare that they have no conflict of interest.

Ethical approval This article does not contain any studies with human participants or animals performed by any of the authors.

Open Access This article is distributed under the terms of the Creative Commons Attribution 4.0 International License (http://creativeco mmons.org/licenses/by/4.0/), which permits unrestricted use, distribution, and reproduction in any medium, provided you give appropriate credit to the original author(s) and the source, provide a link to the Creative Commons license, and indicate if changes were made.

\section{References}

1. Lindholm J, Juul S, Jorgensen JO, Astrup J, Bjerre P, Feldt-Rasmussen U, Hagen C, Jorgensen J, Kosteljanetz M, Kristensen L, Laurberg P, Schmidt K, Weeke J (2001) Incidence and late prognosis of cushing's syndrome: a population-based study. J Clin Endocrinol Metab 86(1):117-123. https://doi.org/10.1210/ jcem.86.1.7093 [doi]

2. Fernandez-Rodriguez E, Stewart PM, Cooper MS (2009) The pituitary-adrenal axis and body composition. Pituitary 12(2):105-115. https://doi.org/10.1007/s11102-008-0098-2

3. Pereira AM, Tiemensma J, Romijn JA (2010) Neuropsychiatric disorders in Cushing's syndrome. Neuroendocrinology 92(Suppl 1):65-70. https://doi.org/10.1159/000314317

4. Hofmann BM, Hlavac M, Martinez R, Buchfelder M, Muller OA, Fahlbusch R (2008) Long-term results after microsurgery for Cushing disease: experience with 426 primary operations over 35 years. J Neurosurg 108(1):9-18. https://doi.org/10.3171/ JNS/2008/108/01/0009

5. Van Haalen FM, Broersen LHA, Jorgensen JO, Pereira AM, Dekkers OM (2015) Management of endocrine disease: mortality remains increased in Cushing's disease despite biochemical remission: a systematic review and meta-analysis. Eur J Endocrinol 172(4):R143-R149

6. Jankowski R, Auque J, Simon C, Marchal JC, Hepner H, Wayoff M (1992) Endoscopic pituitary tumor surgery. Laryngoscope 102(2):198-202. https://doi.org/10.1288/00005537-19920 2000-00016

7. Hardy J (1979) The transsphenoidal surgical approach to the pituitary. Hosp Pract 14(6):81-89

8. Ammirati M, Wei L, Ciric I (2013) Short-term outcome of endoscopic versus microscopic pituitary adenoma surgery: a systematic review and meta-analysis. J Neurol Neurosurg Psychiatry 84(8):843-849. https://doi.org/10.1136/jnnp-2012-303194

9. Alahmadi H, Cusimano MD, Woo K, Mohammed AA, Goguen J, Smyth HS, Macdonald RL, Muller PJ, Horvath E, Kovacs K (2013) Impact of technique on cushing disease outcome using strict remission criteria. Can J Neurol Sci 40(3):334-341

10. Atkinson JL, Young WF Jr, Meyer FB, Davis DH, Nippoldt TB, Erickson D, Vella A, Natt N, Abboud CF, Carpenter PC (2008) Sublabial transseptal vs transnasal combined endoscopic microsurgery in patients with Cushing disease and MRI-depicted microadenomas. Mayo Clin Proc 83(5):550-553

11. Cheng RX, Tian HL, Gao WW, Li ZQ (2011) A comparison between endoscopic trans-sphenoidal surgery and traditional trans-sphenoidal microsurgery for functioning pituitary adenomas. J Int Med Res 39(5):1985-1993. https:// doi.org/10.1177/147323001103900545

12. D’Haens J, Van Rompaey K, Stadnik T, Haentjens P, Poppe K, Velkeniers B (2009) Fully endoscopic transsphenoidal surgery for functioning pituitary adenomas: a retrospective comparison with traditional transsphenoidal microsurgery in the same institution. Surg Neurol 72(4):336-340. https://doi.org/10.1016/j.surne u. 2009.04 .012

13. Goudakos JK, Markou KD, Georgalas C (2011) Endoscopic versus microscopic trans-sphenoidal pituitary surgery: a systematic review and meta-analysis. Clin Otolaryngol 36(3):212-220. https ://doi.org/10.1111/j.1749-4486.2011.02331.x

14. Esquenazi Y, Essayed WI, Singh H, Mauer E, Ahmed M, Christos PJ, Schwartz TH (2017) Endoscopic endonasal versus microscopic transsphenoidal surgery for recurrent and/or residual pituitary adenomas. World Neurosurg 101:186-195. https://doi. org/10.1016/j.wneu.2017.01.110

15. Stroup DF, Berlin JA, Morton SC, Olkin I, Williamson GD, Rennie D, Moher D, Becker BJ, Sipe TA, Thacker SB (2000) Metaanalysis of observational studies in epidemiology: a proposal for reporting. Meta-analysis Of Observational Studies in Epidemiology (MOOSE) group. Jama 283(15):2008-2012

16. Pereira AM, van Aken, MO, van Dulken $H$, Biermasz NR, Smit JW, Roelfsema F, Romijn JA (2003) Long-term predictive value of postsurgical cortisol concentrations for cure and risk of recurrence in Cushing's disease. J Clin Endocrinol Metab 88(12):5858-5864. https://doi.org/10.1210/jc.2003-030751

17. Salassa RM, Laws ER Jr, Carpenter PC, Northcutt RC (1978) Transsphenoidal removal of pituitary microadenoma in Cushing's disease. Mayo Clin Proc 53(1):24-28

18. Rudnik A, Kos-Kudla B, Larysz D, Zawadzki T, Bazowski P (2007) Endoscopic transsphenoidal treatment of hormonally active pituitary adenomas. Neuro Endocrinol Lett 28(4):438-444

19. Acebes JJ, Martino J, Masuet C, Montanya E, Soler J (2007) Early post-operative ACTH and cortisol as predictors of remission in Cushing's disease. Acta Neurochir (Wien) 149(5):471477. https://doi.org/10.1007/s00701-007-1133-1

20. Alexandraki KI, Kaltsas GA, Isidori AM, Storr HL, Afshar F, Sabin I, Akker SA, Chew SL, Drake WM, Monson JP, Besser GM, Grossman AB (2013) Long-term remission and recurrence rates in Cushing's disease: predictive factors in a single-centre study. Eur J Endocrinol 168(4):639-648

21. Alwani RA, de Herder WW, van Aken MO, van den Berge JH, Delwel EJ, Dallenga AH, de Jong FH, Lamberts SW, van der Lely AJ, Feelders RA (2010) Biochemical predictors of outcome of pituitary surgery for Cushing's disease. Neuroendocrinology 91(2):169-178

22. Ammini AC, Bhattacharya S, Sahoo JP, Philip J, Tandon N, Goswami R, Jyotsna VP, Khadgawat R, Chumber S, Seth A, Karak AK, Sharma BS, Chandra PS, Suri A, Sharma MS, Kale SS, Singh M (2011) Cushing's disease: results of treatment and factors affecting outcome. Hormones 10(3):222-229

23. Arnott RD, Pestell RG, McKelvie PA, Henderson JK, McNeill PM, Alford FP (1990) A critical evaluation of transsphenoidal pituitary surgery in the treatment of Cushing's disease: prediction of outcome. Acta Endocrinol (Copenh) 123(4):423-430

24. Asuzu D, Chatain GP, Hayes C, Benzo S, McGlotten R, Keil M, Beri A, Sharma ST, Nieman L, Lodish M, Stratakis C, Lonser RR, Oldfield EH, Chittiboina P (2017) Normalized early postoperative cortisol and ACTH values predict nonremission after surgery for Cushing's disease. J Clin Endocrinol Metab. https:// doi.org/10.1210/jc.2016-3908

25. Bakiri F, Tatai S, Aouali R, Semrouni M, Derome P, Chitour F, Benmiloud M (1996) Treatment of Cushing's disease by transsphenoidal, pituitary microsurgery: prognosis factors and 
long-term follow-up. J Endocrinol Invest 19(9):572-580. https ://doi.org/10.1007/BF03349020

26. Barbetta L, Dall'Asta C, Tomei G, Locatelli M, Giovanelli M, Ambrosi B (2001) Assessment of cure and recurrence after pituitary surgery for Cushing's disease. Acta Neurochir (Wien) 143(5):477-481

27. Barbot M, Albiger N, Koutroumpi S, Ceccato F, Frigo AC, Manara R, Fassina A, Gardiman MP, Scanarini M, Mantero F, Scaroni C (2013) Predicting late recurrence in surgically treated patients with Cushing's disease. Clin Endocrinol (Oxf) 79(3):394-401. https://doi.org/10.1111/cen.12133

28. Barzaghi LR, Losa M, Giovanelli M, Mortini P (2007) Complications of transsphenoidal surgery in patients with pituitary adenoma: experience at a single centre. Acta Neurochir (Wien) 149(9):877-885. https://doi.org/10.1007/s00701-007-1244-8 (discussion 885-876)

29. Bay JW, Sheeler LR (1988) Results of transsphenoidal surgery for Cushing's disease. Cleveland Clinic experience. Cleveland Clin J Med 55(4):357-364

30. Bigos ST, Somma M, Rasio E, Eastman RC, Lanthier A, Johnston HH, Hardy J (1980) Cushing's disease: management by transsphenoidal pituitary microsurgery. J Clin Endocrinol Metab 50(2):348-354. https://doi.org/10.1210/jcem-50-2-348

31. Blevins J, Christy JH, Khajavi M, Tindall GT (1998) Outcomes of therapy for Cushing's disease due to adrenocorticotropinsecreting pituitary macroadenomas. J Clin Endocrinol Metab 83(1):63-67

32. Burkhardt T, Schmidt NO, Vettorazzi E, Aberle J, Mengel M, Flitsch J (2013) DHEA(S)--a novel marker in Cushing's disease. Acta Neurochir (Wien) 155(3):479-484. https://doi. org/10.1007/s00701-012-1596-6

33. Chandler WF, Barkan AL, Hollon T, Sakharova A, Sack J, Brahma B, Schteingart DE (2016) Outcome of transsphenoidal surgery for cushing disease: a single-center experience over 32 years. Neurosurgery 78(2):216-223. https://doi.org/10.1227/ NEU.0000000000001011

34. Chee GH, Mathias DB, James RA, Kendall-Taylor P (2001) Transsphenoidal pituitary surgery in Cushing's disease: can we predict outcome? Clin Endocrinol (Oxf) 54(5):617-626

35. Chen JC, Amar AP, Choi S, Singer P, Couldwell WT, Weiss MH (2003) Transsphenoidal microsurgical treatment of Cushing disease: postoperative assessment of surgical efficacy by application of an overnight low-dose dexamethasone suppression test. J Neurosurg 98(5):967-973. https://doi.org/10.3171/ jns.2003.98.5.0967

36. Ciric I, Zhao JC, Du H, Findling JW, Molitch ME, Weiss RE, Refetoff S, Kerr WD, Meyer J (2012) Transsphenoidal surgery for Cushing disease: experience with 136 patients. Neurosurgery 70(1):70-80. https://doi.org/10.1227/NEU.0b013e3182 2dda2c

37. Donofrio CA, Losa M, Gemma M, Giudice L, Barzaghi LR, Mortini P: Safety of transsphenoidal microsurgical approach in patients with an ACTH-secreting pituitary adenoma. Endocrine (2016). https://doi.org/10.1007/s12020-016-1214-0

38. Erem C, Algun E, Ozbey N, Azezli A, Aral F, Orhan Y, Molvalilar S, Sencer E (2003) Clinical laboratory findings and results of therapy in 55 patients with Cushing's syndrome. J Endocrinol Invest 26(1):65-72

39. Esposito F, Dusick JR, Cohan P, Moftakhar P, McArthur D, Wang C, Swerdloff RS, Kelly DF (2006) Clinical review: Early morning cortisol levels as a predictor of remission after transsphenoidal surgery for Cushing's disease. J Clin Endocrinol Metab 91(1):7-13

40. Flitsch J, Knappe UJ, Ludecke DK (2003) The use of postoperative ACTH levels as a marker for successful transsphenoidal microsurgery in Cushing's disease. Zentralbl Neurochir 64(1):611. https://doi.org/10.1055/s-2003-37145

41. Gazioglu N, Ulu MO, Ozlen F, Albayram S, Islak C, Kocer N, Oz B, Tanriover N, Yetkin DO, Gundogdu S, Acbay O, Kadioglu P (2008) Management of Cushing's disease using cavernous sinus sampling: effectiveness in tumor lateralization. Clin Neurol Neurosurg 110(4):333-338

42. Gsponer J, De TN, Deruaz JP, Janzer R, Uske A, Mirimanoff RO, Reymond MJ, Rey F, Temler E, Gaillard RC, Gomez F (1999) Diagnosis, treatment, and outcome of pituitary tumors and other abnormal intrasellar masses. Retrospective analysis of 353 patients. Medicine (Baltimore) 78(4):236-269

43. Guilhaume B, Bertagna X, Thomsen M, Bricaire C, Vila-Porcile E, Olivier L, Racadot J, Derome P, Laudat MH, Girard F (1988) Transsphenoidal pituitary surgery for the treatment of Cushing's disease: results in 64 patients and long term followup studies. J Clin Endocrinol Metab 66(5):1056-1064. https:// doi.org/10.1210/jcem-66-5-1056

44. Hammer GD, Tyrrell JB, Lamborn KR, Applebury CB, Hannegan ET, Bell S, Rahl R, Lu A, Wilson CB (2004) Transsphenoidal microsurgery for Cushing's disease: initial outcome and long-term results. J Clin Endocrinol Metab 89(12):6348-6357

45. Honegger J, Schmalisch K, Beuschlein F, Kaufmann S, Schnauder G, Naegele T, Psaras T (2012) Contemporary microsurgical concept for the treatment of Cushing's disease: endocrine outcome in 83 consecutive patients. Clin Endocrinol (Oxf) 76(4):560-567. https://doi.org/10.111 $1 / \mathrm{j} .1365-2265.2011 .04268 . \mathrm{x}$

46. Hoybye C, Grenback E, Thoren M, Hulting AL, Lundblad L von, Anggard HH (2004) A.: Transsphenoidal surgery in Cushing disease: 10 years of experience in 34 consecutive cases. J Neurosurg 100(4):634-638. https://doi.org/10.3171/ jns.2004.100.4.0634

47. Huan C, Lu C, Xu G-M, Qu X, Qu Y-M (2014) Retrospective analysis of Cushing's disease with or without hyperprolactinemia. Int J Endocrinol https://doi.org/10.1155/2014/919704

48. Imaki T, Tsushima T, Hizuka N, Odagiri E, Murata Y, Suda T, Takano K (2001) Postoperative plasma cortisol levels predict long-term outcome in patients with Cushing's disease and determine which patients should be treated with pituitary irradiation after surgery. Endocr J 48(1):53-62

49. Inder WJ, Espiner EA, MacFarlane MR (2003) Outcome from surgical management of secretory pituitary adenomas in Christchurch, New Zealand. Int Med J 33(4):168-173

50. Jagannathan J, Smith R, DeVroom HL, Vortmeyer AO, Stratakis CA, Nieman LK, Oldfield EH (2009) Outcome of using the histological pseudocapsule as a surgical capsule in Cushing disease Clinical article. J Neurosurg 111(3):531-539

51. Jehle S, Walsh JE, Freda PU, Post KD (2008) Selective use of bilateral inferior petrosal sinus sampling in patients with adrenocorticotropin-dependent Cushing's syndrome prior to transsphenoidal surgery. J Clin Endocrinol Metab 93(12):4624-4632

52. Knappe UJ, Engelbach M, Konz K, Lakomek HJ, Saeger W, Schonmayr R, Mann WA (2011) Ultrasound-assisted microsurgery for Cushing's disease. Exp Clin Endocrinol Diabetes 119(4):191-200. https://doi.org/10.1055/s-0029-1241207

53. Kristof RA, Schramm J, Redel L, Neuloh G, Wichers M, Klingmuller D (2002) Endocrinological outcome following first time transsphenoidal surgery for GH-, ACTH-, and PRL-secreting pituitary adenomas. Acta Neurochir (Wien) 144(6):555-561. https://doi.org/10.1007/s00701-002-0938-1

54. Kurosaki M, Luedecke DK, Knappe UJ, Flitsch J, Saeger W (2000) The value of intraoperative cytology during transsphenoidal surgery for ACTH-secreting microadenoma. Acta Neurochir (Wien) 142(8):865-870 
55. Lampropoulos KI, Samonis G, Nomikos P (2013) Factors influencing the outcome of microsurgical transsphenoidal surgery for pituitary adenomas: a study on 184 patients. Hormones (Athens) 12(2):254-264

56. Ludecke DK, Niedworok G (1985) Results of microsurgery in Cushing's disease and effect on hypertension. Cardiology 72(Suppl 1):91-94

57. Ludecke DK (1991) Transnasal microsurgery of Cushing's disease 1990. Overview including personal experiences with 256 patients. Pathol Res Pract 187(5):608-612

58. Mampalam TJ, Tyrrell JB, Wilson CB (1988) Transsphenoidal microsurgery for Cushing disease. A report of 216 cases. Ann Intern Med 109(6):487-493

59. Mehrazin M (2004) Cushing's disease, transsphenoidal surgical results of 11 cases. Arch Iran Med 7(1):53-56

60. Mortini P, Losa M, Barzaghi R, Boari N, Giovanelli M (2005) Results of transsphenoidal surgery in a large series of patients with pituitary adenoma. Neurosurgery 56(6):1222-1233 (discussion 1233)

61. Nakane T, Kuwayama A, Watanabe M, Takahashi T, Kato T, Ichihara K, Kageyama N (1987) Long term results of transsphenoidal adenomectomy in patients with Cushing's disease. Neurosurgery 21(2):218-222

62. Nemergut EC, Zuo Z, Jane JA Jr, Laws ER Jr (2005) Predictors of diabetes insipidus after transsphenoidal surgery: a review of 881 patients. J Neurosurg 103(3):448-454. https://doi.org/10.3171/ jns.2005.103.3.0448

63. Norris JS, Newell-Price J, Trainer PJ, Grossman AB, Plowman PN, Besser GM, Afshar F: P-5-616 - Investigation, management and treatment outcome in 100 patients with Cushings' disease, following transsphenoidal surgery. Paper presented at the Clinical Neurology and Neurosurgery, 11th International Congress of Neurological Surgery, 7/1997

64. Patil CG, Prevedello DM, Lad SP, Vance ML, Thorner MO, Katznelson L, Laws ER Jr (2008) Late recurrences of Cushing's disease after initial successful transsphenoidal surgery. J Clin Endocrinol Metab 93(2):358-362

65. Patil CG, Veeravagu A, Prevedello DM, Katznelson L, Vance ML, Laws ER Jr (2008) Outcomes after repeat transsphenoidal surgery for recurrent Cushing's disease. Neurosurgery 63(2):266-270

66. Petruson K, Jakobsson KE, Petruson B, Lindstedt G, Bengtsson BA (1997) Transsphenoidal adenomectomy in Cushing's disease via a lateral rhinotomy approach. Surg Neurol 48(1):37-43

67. Pieters GF, Hermus AR, Meijer E, Smals AG, Kloppenborg PW (1989) Predictive factors for initial cure and relapse rate after pituitary surgery for Cushing's disease. J Clin Endocrinol Metab 69(6):1122-1126. https://doi.org/10.1210/jcem-69-6-1122

68. Pikkarainen L, Sane T, Reunanen A (1999) The survival and well-being of patients treated for Cushing's syndrome. J Intern Med 245(5):463-468

69. Pimentel-Filho FR, Silva ME, Nogueira KC, Berger K, Cukiert A, Liberman B (2005) Pituitary-adrenal dynamics after ACTHsecreting pituitary tumor resection in patients receiving no steroids post-operatively. J Endocrinol Invest 28(6):502-508

70. Post A (1995) Pituitary function after selective adenomectomy for Cushing's disease. Br J Neurosurg 9(1):41-46. https://doi. org/10.1080/02688699550041737

71. Potts MB, Shah JK, Molinaro AM, Blevins LS, Tyrrell JB, Kunwar S, Dowd CF, Hetts SW, Aghi MK (2014) Cavernous and inferior petrosal sinus sampling and dynamic magnetic resonance imaging in the preoperative evaluation of Cushing's disease. J Neurooncol 116(3):593-600. https://doi.org/10.1007/s1106 0-013-1342-9
72. Powell MP, Narimova GJ, Halimova ZJ (2017) The results of surgical treatment of cushing tumors in the republic of Uzbekistan: establishing transsphenoidal surgery in a developing nation. World Neurosurg 97:213-220

73. Rollin G, Ferreira NP, Czepielewski MA (2007) Prospective evaluation of transsphenoidal pituitary surgery in 108 patients with Cushing's disease. Arq Bras Endocrinol Metabol 51(8):1355-1361

74. Semple CG, Thomson JA, Teasdale GM (1984) Transsphenoidal microsurgery for Cushing's disease. Clin Endocrinol (Oxf) 21(6):621-629

75. Semple PL, Laws ER Jr (1999) Complications in a contemporary series of patients who underwent transsphenoidal surgery for Cushing's disease. J Neurosurg 91(2):175-179. https://doi. org/10.3171/jns.1999.91.2.0175

76. Shah NS, Goel AH, Nagpal RD, Menon PS (2006) Cushing's disease: management outcome in a tertiary care centre. J Assoc Phys India 54:919-922

77. Shimon I, Ram Z, Cohen ZR, Hadani M (2002) Transsphenoidal surgery for Cushing's disease: endocrinological follow-up monitoring of 82 patients. Neurosurgery 51(1):57-61

78. Shirvani M, Motiei-Langroudi R, Sadeghian H (2016) Outcome of microscopic transsphenoidal surgery in Cushing disease: a case series of 96 patients. World Neurosurg 87:170-175

79. Sonino N, Zielezny M, Fava GA, Fallo F, Boscaro M (1996) Risk factors and long-term outcome in pituitary-dependent Cushing's disease. J Clin Endocrinol Metab 81(7):2647-2652. https://doi. org/10.1210/jcem.81.7.8675592

80. Sudhakar N, Ray A, Vafidis JA (2004) Complications after transsphenoidal surgery: our experience and a review of the literature. Br J Neurosurg 18(5):507-512

81. Swearingen B, Biller BM, Barker FG, Katznelson L, Grinspoon S, Klibanski A, Zervas NT (1999) Long-term mortality after transsphenoidal surgery for Cushing disease. Ann Intern Med 130(10):821-824

82. Valderrabano P, Aller J, Garcia-Valdecasas L, Garcia-Uria J, Martin L, Palacios N, Estrada J (2014) Results of repeated transsphenoidal surgery in Cushing's disease. Long-term follow-up. Endocrinol Nutr 61(4):176-183

83. Vallette-Kasic S, Dufour H, Mugnier M, Trouillas J, ValdesSocin H, Caron P, Morange S, Girard N, Grisoli F, Jaquet P, Brue T (2000) Markers of tumor invasion are major predictive factors for the long-term outcome of corticotroph microadenomas treated by transsphenoidal adenomectomy. Eur J Endocrinol 143(6):761-768

84. Witek P, Zielinski G, Maksymowicz M, Zgliczynski W (2012) The relationship between efficacy of surgical treatment of Cushing disease and pathological-immunohistochemical and ultrastructural-confirmation of corticotroph tumour presence. Neurol Neurochir Pol 46(1):37-46

85. Witek P, Zielinski G, Szamotulska K, Witek J, Kaminski G (2016) Cushing`s disease: fibrinogen and D-dimer levels fail to normalize despite early postoperative remission-a prospective, controlled study. Endokrynol Pol 67(3):283-291

86. Yap LB, Turner HE, Adams CB, Wass JA (2002) Undetectable postoperative cortisol does not always predict long-term remission in Cushing's disease: a single centre audit. Clin Endocrinol (Oxf) 56(1):25-31

87. Berker M, Isikay I, Berker D, Bayraktar M, Gurlek A (2013) Early promising results for the endoscopic surgical treatment of Cushing's disease. Neurosurg Rev. https://doi.org/10.1007/s1014 3-013-0506-6

88. Cebula H, Baussart B, Villa C, Assie G, Boulin A, Foubert L, Aldea S, Bennis S, Bernier M, Proust F, Gaillard S (2017) Efficacy of endoscopic endonasal transsphenoidal surgery for 
Cushing's disease in 230 patients with positive and negative MRI. Acta Neurochir (Wien). https://doi.org/10.1007/s0070 1-017-3140-1

89. Dehdashti AR, Gentili F (2007) Current state of the art in the diagnosis and surgical treatment of Cushing disease: early experience with a purely endoscopic endonasal technique. Neurosurg Focus 23(3):E9. https://doi.org/10.3171/foc.2007.23.3.11

90. Dehdashti AR, Ganna A, Karabatsou K, Gentili F (2008) Pure endoscopic endonasal approach for pituitary adenomas: early surgical results in 200 patients and comparison with previous microsurgical series. Neurosurgery 62(5):1006-1015. https ://doi.org/10.1227/01.neu.0000325862.83961.12 (discussion 1015-1007)

91. Frank G, Pasquini E, Farneti G, Mazzatenta D, Sciarretta V, Grasso V, Fustini F (2006) The endoscopic versus the traditional approach in pituitary surgery. Neuroendocrinology 83(3-4):240 248. https://doi.org/10.1159/000095534

92. Gondim JA, Schops M, de Almeida JP, de Albuquerque LA, Gomes E, Ferraz T, Barroso FA (2010) Endoscopic endonasal transsphenoidal surgery: surgical results of 228 pituitary adenomas treated in a pituitary center. Pituitary 13(1):68-77. https:// doi.org/10.1007/s11102-009-0195-x

93. Hofstetter CP, Nanaszko MJ, Mubita LL, Tsiouris J, Anand VK, Schwartz TH (2012) Volumetric classification of pituitary macroadenomas predicts outcome and morbidity following endoscopic endonasal transsphenoidal surgery. Pituitary 15(3):450-463

94. Hwang YC, Chung JH, Min YK, Lee MS, Lee MK, Kim KW (2009) Comparisons between macroadenomas and microadenomas in Cushing's disease: characteristics of hormone secretion and clinical outcomes. J Korean Med Sci 24(1):46-51. https:// doi.org/10.3346/jkms.2009.24.1.46

95. Jho H-D (2001) Endoscopic transsphenoidal surgery. J NeuroOncol 54(2):187-195

96. Kabil MS, Eby JB, Shahinian HK (2005) Fully endoscopic endonasal vs. transseptal transsphenoidal pituitary surgery. Minim Invasive Neurosurg 48(6):348-354. https://doi. org/10.1055/s-2005-915635

97. Kuo C-H, Yen Y-S, Wu J-C, Chen Y-C, Huang W-C, Cheng H (2015) Primary endoscopic transnasal transsphenoidal surgery for magnetic resonance image-positive Cushing disease: outcomes of a series over 14 years. World Neurosurg 84(3):772-779

98. Leach P, Abou-Zeid AH, Kearney T, Davis J, Trainer PJ, Gnanalingham KK (2010) Endoscopic transsphenoidal pituitary surgery: evidence of an operative learning curve. Neurosurgery 67(5):1205-1212. https://doi.org/10.1227/NEU.0b013e3181 ef $25 \mathrm{c} 5$

99. Mamelak AN, Carmichael J, Bonert VH, Cooper O, Melmed S (2013) Single-surgeon fully endoscopic endonasal transsphenoidal surgery: outcomes in three-hundred consecutive cases. Pituitary 16(3):393-401. https://doi.org/10.1007/ s11102-012-0437-1

100. Masopust V, Netuka D, Bene+í Vr, M+íjovsk++ M, Bel+ítín T, Brad+í-ì O, Ho+Ö+¡nek D, Kos+ík M, H+ína V, Kr+íek M (2017) Magnetic resonance imaging and histology correlation in Cushing's disease. Neurol Neurochir Pol 51(1):45-52

101. Paluzzi A, Fernandez-Miranda JC, Tonya SS, Challinor S, Snyderman CH, Gardner PA (2014) Endoscopic endonasal approach for pituitary adenomas: A series of 555 patients. Pituitary 17(4):307-319

102. Sarkar S, Rajaratnam S, Chacko G, Mani S, Hesargatta AS, Chacko AG: Pure endoscopic transsphenoidal surgery for functional pituitary adenomas: outcomes with Cushing's disease. Acta Neurochir (Wien) 158(1), 77-86 (2016)

103. Senior BA, Ebert CS, Bednarski KK, Bassim MK, Younes M, Sigounas D, Ewend MG (2008) Minimally invasive pituitary surgery. Laryngoscope 118(10):1842-1855. https://doi.org/10.1097/ MLG.0b013e31817e2c43

104. Shin SS, Gardner PA, Ng J, Faraji AH, Agarwal N, Chivukula S, Fernandez-Miranda JC, Snyderman CH, Challinor SM (2015) Endoscopic endonasal approach for adrenocorticotropic hormone-secreting pituitary adenomas: outcomes and analysis of remission rates and tumor biochemical activity with respect to tumor invasiveness. World Neurosurg 102:651-658

105. Starke RM, Reames DL, Chen CJ, Laws ER, Jane JA Jr (2013) Endoscopic transsphenoidal surgery for cushing disease: techniques, outcomes, and predictors of remission. Neurosurgery 72(2):240-247. https://doi.org/10.1227/NEU.0b013e31827b966a

106. Torales J, Halperin I, Hanzu F, Mora M, Alobid I, De NM, Ferrer E, Ensenat J (2014) Endoscopic endonasal surgery for pituitary tumors. Results in a series of 121 patients operated at the same center and by the same neurosurgeon. Endocrinol Nutr 61(8):410-416

107. Wagenmakers MA, Boogaarts HD, Roerink SH, Timmers HJ, Stikkelbroeck NM, Smit JW, van Lindert EJ, Netea-Maier RT, Grotenhuis JA, Hermus AR (2013) Endoscopic transsphenoidal pituitary surgery: a good and safe primary treatment option for Cushing's disease, even in case of macroadenomas or invasive adenomas. Eur J Endocrinol 169(3):329-337

108. Jho HD, Carrau RL (1997) Endoscopic endonasal transsphenoidal surgery: experience with 50 patients. J Neurosurg 87(1):4451. https://doi.org/10.3171/jns.1997.87.1.0044

109. Woo YS, Isidori AM, Wat WZ, Kaltsas GA, Afshar F, Sabin I, Jenkins PJ, Monson JP, Besser GM, Grossman AB (2005) Clinical and biochemical characteristics of adrenocorticotropin-secreting macroadenomas. J Clin Endocrinol Metab 90(8):4963-4969. https://doi.org/10.1210/jc.2005-0070 